\title{
Evaluation of Science Teaching in Secondary Schools in Delta State 2 -Teaching of the Sciences
}

\author{
Ajaja O. Patrick \\ Department of Science Education, Delta State University, Abraka, Nigeria \\ Telephone: 08037230550, E-mail: osawaruajaja@yaboo.com
}

KEYWORDS Period Allocation. Content Coverage. Assignments. Extra Lesson. Assessment

\begin{abstract}
The purpose of this study was to examine the activities which go on in science classrooms in secondary schools in Delta State with the intention of comparing them with both national and international standards. To guide this study ten research questions were raised and answered. The design of the study was survey. The samples of the study consist of 90 senior secondary schools, 90 Principals, 270 science teachers and 22,500 students drawn from the three senatorial districts in Delta State. The major instrument used for data collection was a questionnaire. Other methods used for data collection include; interviews and personal observation. Following the non-development of sound science education in schools, the following science education activities have suffered serious setback: insufficient time allocation in school time table, persistent use of lecture method in science teaching, persistence of teacher dominated teacher-student interaction in science classroom, non-coverage of science schemes of work, non-regular giving and marking of assignments, non-proper supervision of instructions, non-conduction of practical lessons and non-assessment of students in all the domains. It is concluded that the poor state of infrastructure and poorly trained teachers are the causes of poor teaching of science in schools.
\end{abstract}

\section{INTRODUCTION}

Trowbridge and Bybee (1996), Ajaja (2007) identified the objectives of teaching science to include: (i) knowledge of science academic discipline; (ii) to acquire the skills of scientific method; (iii) having clear explanations for societal issues through increasing interest in science literacy and societal goals; (iv) for personal needs; and (v) for career awareness.

In Nigeria, the sciences are taught in school subjects as Biology, Chemistry, and Physics. The National Policy on Education in the National curriculum for Senior Secondary Schools volume 3 Science stated specific objectives to be achieved by each subject curriculum. The cardinal objectives for Biology include: (1) adequate laboratory and field skills in biology; (2) meaningful and relevant knowledge in biology; (3) ability to apply scientific knowledge to everyday life in matters of personal and community health and agriculture; and (4) reasonable and functional scientific attitudes.

For chemistry, the specific objectives to be achieved in the curriculum include: (i) facilitate a transition to the use of scientific concepts and techniques acquired in Integrated Science with chemistry; (2) provide the students with basic knowledge in chemical concepts and principles through efficient selection of content and sequencing: (3) show chemistry in its interrelationship with other subjects; (4) show chemistry and its link with industry, everyday life, benefits and hazards and (5) provide a course which is complete for pupils not proceeding to higher education while it is at the same time a reasonably adequate foundation for a postsecondary chemistry course.

The physics curriculum has these objectives to achieve: (i) to provide basic literacy in physics for functional living in the society; (ii) to acquire basic concepts and principles of physics as a presentation for further studies; (iii) to acquire essential scientific skills and attitudes as a preparation for the technological application of physics and (iv) to simulate and enhance creativity.

All these objectives whether general or specific are only achieved by the teacher through giving the right types of instructions to the science students. No matter how well-developed and comprehensive a curriculum is, its success is dependent on the quality of the teachers implementing it (Onwuka 1985; Ughamadu 2005). The Federal Republic of Nigeria (2004) while stressing the importance of teacher quality' in curriculum implementation noted that no nation's educational system can rise above the quality of her teachers.

Science teaching world wide has standards. 
These standards must be followed if the national or specific objectives of science education are to be achieved. Trowbridge and Bybee (1996) identified six component of a model for standard science teaching in United States of America include: (i) teachers of science should plan inquiry-based programme for their students; (ii) teachers should interact with students to focus and support their inquires, recognize individual differences and provide opportunities for all pupils to learn; (iii) teachers should engage in ongoing assessment of their teaching and resulting students learning; (iv) conditions for learning should provide students with time, space, and resources needed for successful science learning; (v) teachers should foster habits of mind, attitudes, and values of science by being good role models for these attributes and (vi) it is important for teachers to become active participants in on-going planning and development of the school science programme.

Although these bench-marks were derived from American Science education specifications they are by no means limited to United States alone. This same standard is recommended in all science classrooms world wide. The realizations of these standards vary among nations because of variation in commitment to achieve and maintain the set standards. Most poor nations lack resources to enforce standards in science teaching and learning.

The practiced competencies of science teachers can be derived from what they actually do in schools and particularly in the science classrooms. Although the National Policy on Education was lunched in 1982 and by 1985 all states of the federation have joined in the implementation. It is regrettable to note that after this long, most research findings on the implementation of the policy indicate that most of the provisions in the policy are not adhered to. Ivowi (1997) noted that there is wide disparity in the concept of implementation amongst teachers, planners and administrators. The areas in science education practices which are not in conformity with the provisions in the National Policy on Education range from methods of instruction to the exhibition of professional qualities in terms of activities and behaviour.

Research results (Aminu 1980; Abijo 1981; Oludotun and Oguniyi 1981; Jegede 1982; Ivowi 1997; Ajaja 1998; Ajaja 2005) have shown that science teachers continue to teach science using the lecture method despite the recommended guided discovery/inquiry methods and the acceptance of these methods by teachers at organized training and orientation courses. The inability of science teachers to apply guided discovery/inquiry approaches in their teaching is hinged on some teething problems which include; lack of laboratories equipped with facilities in schools; large class sizes of science students with very few teachers and competency problems arising from the training of science teachers. Research evidences according to Ivowi (1997) now exist to suggest that students' misconception in science and mathematics may be due to teaching and that teachers do not seem to know the level of misconception in their students. Ajaja (1998) found that biology students taught with guided discovery and invention methods retrained biology knowledge longer than those taught with lecture method. This tends to suggest that poor science learning by students is traced to the teachers' fault-in the area of competences.

Daily observation of science teachers in the classrooms indicate that most of the teaching skills science teachers acquired before certification are not put into practice. The deficiencies in science teaching range from; noncoverage of contents in schemes of work, nongiving and marking of assignments, nonsupervision of instruction, non-organization of practical lessons, non-organization of extra lessons to cover lost grounds, non-assessment of learning outcomes regularly, non-application of improvisation knowledge in instruction to nontaking out of students to field experiences. Again all these tend to suggest that teachers are to be blamed for the lack of proper exposure of the science students-which result in poor learning outcomes among the science students.

This study which is a following-up of an earlier study on the state of resource materials for teaching and learning science, was in part necessitated by a protracted long period of poor performance of science students (Aghenta 1982; Urevbu 1987; Ajaja 2002; WAEC 2004, 2005, 2006, 2007). This study is mainly aimed at finding out the extent to which our practices in science classrooms agree with the recommended international standards of science teaching. This study will specifically investigate issues like: time allocation to science subjects, pattern of classroom interaction, methods of instruction, 
supervision of instruction, coverage of subject content, giving and marking of assignments, organization of practical lessons, organization of extra lessons at no cost, and evaluation of learning outcome.

\section{Statement of Problem}

This study was carried out in an attempt to identify the problems hindering the effective teaching and learning of sciences in secondary schools in Delta State of Nigeria. The teaching and learning of sciences have standards to be followed by science teachers if effective learning by students is to be achieved. Literature in this area appears very scanty and as a result, our knowledge of what science teachers do in the classrooms is very limited. This therefore calls for more research efforts directed towards this very important aspect of science teaching. Literature in this area also indicates that no research efforts were directed at comparing our standard of science teaching with recommended standards world wide. It is very important to compare our standard in science teaching as presently constituted with the international standards to enable us improve in science teaching. The statement of the problem therefore is, will the evaluation of how science teachers teach sciences in the classrooms and their comparison with international standards generate ideas on how to improve science teaching in secondary schools in Delta State?

\section{Research Questions}

To guide this study, the following research questions were raised, and answered after through investigation.

1. What number of periods is allocated to science teaching in school time table?

2. What is the pattern of interaction in science classroom?

3. What instructional methods are used for teaching science in schools?

4. What is the extent of coverage of contents in science syllabuses in schools?

5. How often are assignments given and marked in science subjects?

6. How is science instruction supervised in schools?

7. How often are science practical lessons organized in our schools?
8. How often are extra-lessons to cover contents in science syllabuses organized in our schools?

9. How is learning-outcome evaluated in schools?

10. What learning-outcomes are evaluated in school science?

\section{METHODOLOGY}

\section{Design of the Study}

The design employed for the study was survey. This design was most appropriate and suitable for the study since questionnaire was the major instrument used for collection of data from the sampled segment of the society of interest. As a rule, any study which employs the questionnaire in the collection of data is a survey research. The findings from the sampled segment of the population are used to generalize for the entire population. A little part of the study employed an observational study design.

\section{Population and Sample of the Study}

The population of study consists of all the senior secondary schools in Delta State. The population of the senior secondary school science students is 195,775 . The samples of the study include: 90 Senior Secondary Schools; 30 from each of the three senatorial districts in Delta State, 90 School Principals, 270 Science Teachers and 22,500 Students. The three senatorial districts in Delta State include Delta North, Delta Central, and Delta South. The study employed a proportionate random sampling technique in the collection of samples. Using balloting (withdrawal replacement technique), 30 Senior Secondary Schools were selected from each of the three senatorial districts. Intact classes were used for all the science subjects.

\section{Instruments}

The major instrument used for data collection was a questionnaire called Science Teachers Questionnaires. The questionnaire consists of 17 items which generated data for answering nine out of the ten research questions. Other strategies employed in data collection include: interviews and personal observation of what goes on in science classrooms with the science classroom 
interaction category adapted by Ajaja (2005) from Shamansky's Science Laboratory interaction category. No further validation of the adapted classroom interaction category was done again since it has been done before. The reliability of the instrument was put at 0.76 .

The questionnaire was validated by a jury of three experienced science teachers; one each from Biology, Chemistry, and Physics, and an expert in Measurement and Evaluation. Since content validity was what was determined, the choice of a jury and its composition was accurate and agrees with the recommendations of (Wiseman 1999; Johnson and Christensen 2000). The reliability of the questionnaires was found to be 0.77 using the inter-rater reliability method. As a rule, a high reliability of 0.70 or higher shows that a test is reliable (accurately) measuring the characteristics it was designed to measure (Thorndike and Hagen 1977; Wiseman 1999; Johnson and Christensen 2000; and Borich 2004).

\section{Procedure for Data Collection}

The researcher employed the services of three research assistants in the collection of data. The researcher together with the three research assistants; one from each senatorial district administered the questionnaires on the 270 science teachers in the sampled schools. Two days was spent for the administration of questionnaire, collection of classroom interaction data by observation with the classroom interaction category and interviewing of science teachers in each of the senatorial districts. All the questionnaires were collected from the respondents as soon as they finished with their responses. Their responses were scored, summarized and presented in tables. Using the science classroom interaction category, the researcher personally observed three science students in each science classroom in each school visited and for 10 minutes each. The time spent on each item in the category was expressed in percentages. The major statistic used for the analysis of collected data was simple percentage.

\section{RESULTS}

\section{Period Allocation}

Table 1 shows that the number of periods allocated for teaching each of science subjects per week is 4 . The periods are arranged to specify

Table 1: Period allocation for teaching science in school time table

\begin{tabular}{|c|c|c|c|c|c|}
\hline $\begin{array}{l}\text { Senatorial } \\
\text { district }\end{array}$ & $\begin{array}{l}\text { Science } \\
\text { subjects }\end{array}$ & $\begin{array}{c}\text { Average No. } \\
\text { of periods } \\
\text { in Public } \\
\text { Schools }\end{array}$ & $\begin{array}{c}\text { Average No. } \\
\text { of periods } \\
\text { in Private } \\
\text { Schools }\end{array}$ & $\begin{array}{c}\text { Period } \\
\text { distribution } \\
\text { pattern in } \\
\text { Public Schools }\end{array}$ & $\begin{array}{c}\text { Period distribution } \\
\text { pattern in Private } \\
\text { Schools }\end{array}$ \\
\hline \multirow{6}{*}{$\begin{array}{l}\text { Delta } \\
\text { North }\end{array}$} & \multirow[t]{2}{*}{ Biology } & \multirow[t]{2}{*}{4} & \multirow[t]{2}{*}{4} & 2 Single Period & 2 Single Period \\
\hline & & & & 1 Double Period & 1 Double Period \\
\hline & \multirow[t]{2}{*}{ Chemistry } & \multirow[t]{2}{*}{4} & \multirow[t]{2}{*}{4} & 2 Single Period & 2 Single Period \\
\hline & & & & 1 Double Period & 1 Double Period \\
\hline & \multirow[t]{2}{*}{ Physics } & \multirow[t]{2}{*}{4} & \multirow[t]{2}{*}{4} & 2 Single Period & 2 Single Period \\
\hline & & & & 1 Double Period & 1 Double Period \\
\hline \multirow{6}{*}{$\begin{array}{l}\text { Delta } \\
\text { Central }\end{array}$} & \multirow[t]{2}{*}{ Biology } & \multirow[t]{2}{*}{4} & \multirow[t]{2}{*}{4} & 2 Single Period & 2 Single Period \\
\hline & & & & 1 Double Period & 1 Double Period \\
\hline & \multirow{2}{*}{ Chemistry } & \multirow[t]{2}{*}{4} & \multirow[t]{2}{*}{4} & 2 Single Period & 2 Single Period \\
\hline & & & & I Double Period & 1 Double Period \\
\hline & \multirow[t]{2}{*}{ Physics } & \multirow[t]{2}{*}{4} & \multirow[t]{2}{*}{4} & 2 Single Period & 2 Single Period \\
\hline & & & & 1 Double Period & 1 Double Period \\
\hline \multirow{6}{*}{$\begin{array}{l}\text { Delta } \\
\text { South }\end{array}$} & \multirow{2}{*}{ Biology } & \multirow[t]{2}{*}{4} & \multirow[t]{2}{*}{4} & 2 Single Period & 2 Single Period \\
\hline & & & & 1 Double Period & 1 Double Period \\
\hline & \multirow[t]{2}{*}{ Chemistry } & \multirow[t]{2}{*}{4} & \multirow[t]{2}{*}{4} & 2 Single Period & 2 Single Period \\
\hline & & & & 1 Double Period & 1 Double Period \\
\hline & \multirow[t]{2}{*}{ Physics } & \multirow[t]{2}{*}{4} & \multirow[t]{2}{*}{4} & 2 Single Period & 2 Single Period \\
\hline & & & & 1 Double Period & 1 Double Period \\
\hline \multirow{6}{*}{$\begin{array}{l}\text { State } \\
\text { Average }\end{array}$} & \multirow[t]{2}{*}{ Biology } & \multirow[t]{2}{*}{4} & \multirow[t]{2}{*}{4} & 2 Single Period & 2 Single Period \\
\hline & & & & 1 Double Period & 1 Double Period \\
\hline & Chemistry & 4 & 4 & 2 Single Period & 2 Single Period \\
\hline & & & & 1 Double Period & 1 Double Period \\
\hline & Physics & 4 & 4 & 2 Single Period & 2 Single Period \\
\hline & & & & 1 Double Period & 1 Double Period \\
\hline
\end{tabular}


two single periods and one double period. Each period lasts for 45 minutes. This pattern of period allocation is the same for both public and private schools.

\section{Interaction in Science Classroom}

Table 2 shows that in Delta State, the pattern of interaction in science classrooms is the teacher initiated and dominated interaction. This pattern is similar for both the public and private schools. The table indicates that in Biology the percentage of class time spent on teacher-student interaction is $83 \%$ for both public and private schools. For chemistry, the percentage of class time spent on teacher-student interaction is $87 \%$ in public schools and $85 \%$ in private schools. Physics has $93 \%$ and $88 \%$ of class time being spent on teacherstudent interaction in public and private schools respectively.

\section{Method of Instruction}

Table 3 shows that the major method of science instruction in Delta State is expository method. All the sampled schools in all the senatorial districts used the expository method as the main method of instruction in science classrooms. Only a very low percentage of the schools combine the expository method with laboratory method in teaching science.

\section{Coverage of Scheme of Work}

Shown in Table 4, none of the sampled schools in the state covered the scheme of work for all the science subjects at the end of the session in both public and private schools. The levels of coverage of schemes of work are: (i) Biology $77 \%$ in public schools as against $97 \%$ in private schools; (ii) chemistry $80 \%$ in public schools as against $97 \%$

Table 2: Pattern of interaction in science classroom

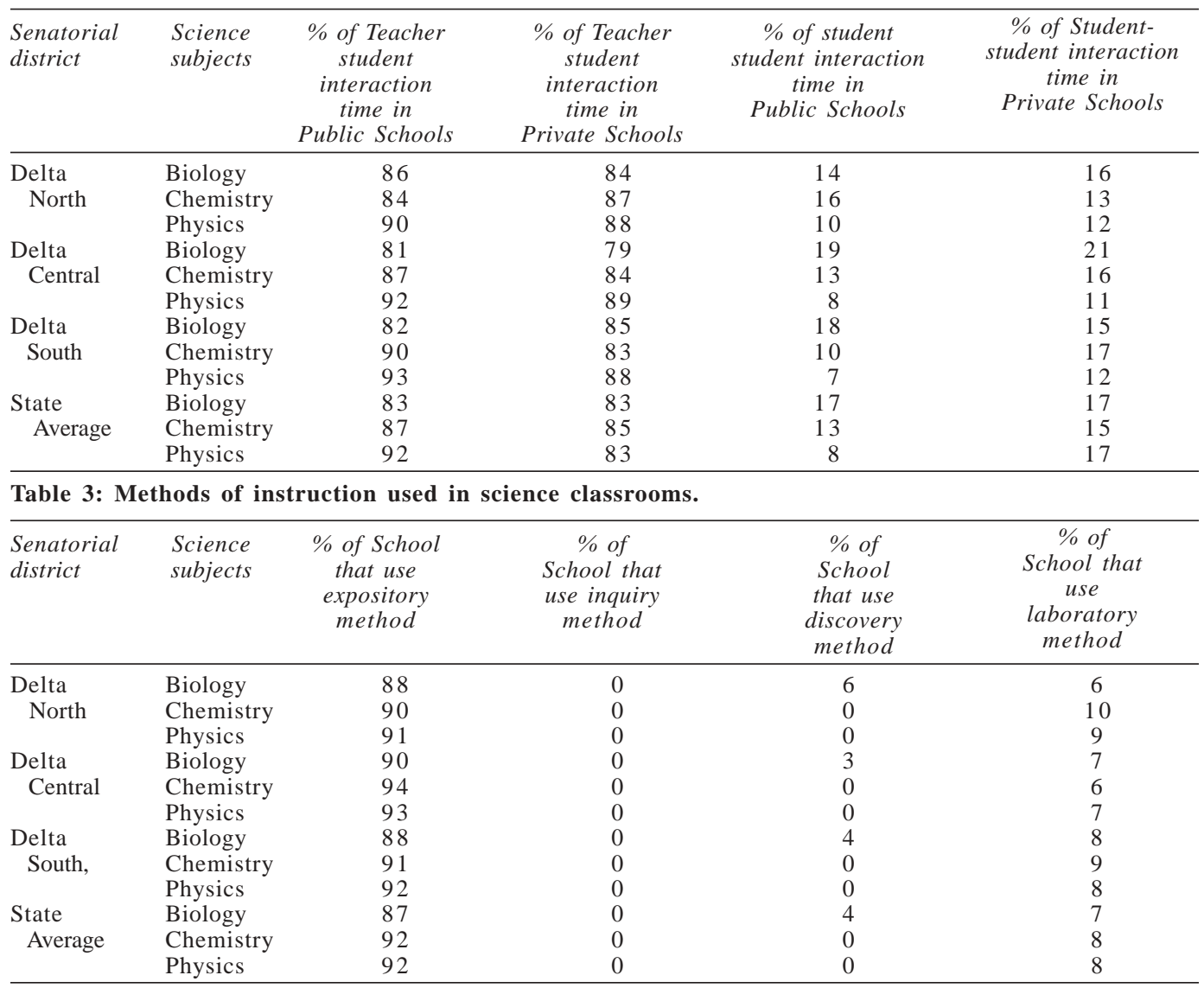


Table 4: Extent of coverage of content in scheme of work

\begin{tabular}{|c|c|c|c|c|c|c|c|c|c|c|c|c|c|}
\hline \multirow{2}{*}{$\begin{array}{l}\text { Senatorial } \\
\text { district }\end{array}$} & \multirow{2}{*}{$\begin{array}{l}\text { Science } \\
\text { subjects }\end{array}$} & \multicolumn{6}{|c|}{ Public schools } & \multicolumn{6}{|c|}{ Private schools } \\
\hline & & $100 \% 90 \%$ & $80 \%$ & $70 \%$ & $60 \%$ & $50 \%$ & $40 \%$ & $100 \% 90 \%$ & $80 \%$ & $70 \%$ & $60 \%$ & $50 \%$ & $40 \%$ \\
\hline \multirow{3}{*}{$\begin{array}{l}\text { Delta } \\
\text { North }\end{array}$} & Biology & & $\sqrt{ }$ & & & & & $\sqrt{ }$ & & & & & \\
\hline & Chemistry & & $\sqrt{ }$ & & & & & $\sqrt{ }$ & & & & & \\
\hline & Physics & & & $\sqrt{ }$ & & & & $\sqrt{ }$ & & & & & \\
\hline \multirow{3}{*}{$\begin{array}{l}\text { Delta } \\
\text { Central }\end{array}$} & Biology & & & $\sqrt{ }$ & & & & $\sqrt{ }$ & & & & & \\
\hline & Chemistry & & $\sqrt{ }$ & & & & & $\sqrt{ }$ & & & & & \\
\hline & Physics & & $\sqrt{ }$ & & & & & $\sqrt{ }$ & & & & & \\
\hline \multirow{3}{*}{$\begin{array}{l}\text { Delta } \\
\text { South }\end{array}$} & Biology & & $\sqrt{ }$ & & & & & $\sqrt{ }$ & & & & & \\
\hline & Chemistry & & $\sqrt{ }$ & & & & & $\sqrt{ }$ & & & & & \\
\hline & Physics & & $\sqrt{ }$ & & & & & $\sqrt{ }$ & & & & & \\
\hline \multirow{3}{*}{$\begin{array}{l}\text { State } \\
\text { Average }\end{array}$} & Biology & & $77 \%$ & & & & & $97 \%$ & & & & & \\
\hline & Chemistry & & $80 \%$ & & & & & $97 \%$ & & & & & \\
\hline & Physics & & $77 \%$ & & & & & $90 \%$ & & & & & \\
\hline
\end{tabular}

in private schools; (iii) physics $77 \%$ in public schools as against $90 \%$ in private schools.

\section{Giving and Marking Assignments}

Table 5 shows that the giving and marking of assignments by science teachers is not consistent in public schools. Assignments are given and marked once a while in public schools. The table also shows that in private schools, giving and marking of assignment in science subjects is once a week.

\section{Supervision of Instruction}

Shown in Table 6, in all schools, supervision of instructions in all science classrooms are done by the School Principals and their vices. The frequency of the inspection as shown in Table 7 follows this order and sequence. In Public Schools, inspection of instructional activities in science classrooms take place when there is noise coming from a particular classroom and prior to the visit of Federal/State inspectors of education. The supervision of instruction in private schools is mainly carried out when noise is noticed from a particular class.

\section{Organization of Practical}

Table 8 shows that science practical lessons are organized only during the preparation for external examinations for final year students in public schools. Also shown in the table, private schools organize practical lessons for biology once a month, once a term for chemistry and when preparing for external examinations for all science subjects.

\section{Organization of Extra-Lesson}

Shown in Table 9, the organization of extra lessons to cover scheme of work in public schools is reserved only for the final year students and

Table 5: Giving and marking assignmentsa

\begin{tabular}{|c|c|c|c|c|c|c|c|c|c|}
\hline \multirow{2}{*}{$\begin{array}{l}\text { Senatorial } \\
\text { district }\end{array}$} & \multirow{2}{*}{$\begin{array}{l}\text { Science } \\
\text { subjects }\end{array}$} & \multicolumn{4}{|c|}{ Public schools } & \multicolumn{4}{|c|}{ Private schools } \\
\hline & & $\begin{array}{l}\text { Every } \\
\text { lesson }\end{array}$ & $\begin{array}{l}\text { Week- } \\
\text { ly }\end{array}$ & $\begin{array}{c}\text { Month- } \\
\text { ly }\end{array}$ & $\begin{array}{c}\text { Once a Not at } \\
\text { while all }\end{array}$ & $\begin{array}{l}\text { Every } \\
\text { lesson }\end{array}$ & $\begin{array}{c}\text { Week- Month- } \\
\text { ly } \quad l y\end{array}$ & $\begin{array}{c}\text { Once a } \\
\text { while }\end{array}$ & $\begin{array}{l}\text { Not at } \\
\quad \text { all }\end{array}$ \\
\hline \multirow[t]{3}{*}{ DeltaNorth } & Biology & & & & $\sqrt{ }$ & & $\sqrt{ }$ & & \\
\hline & Chemistry & & & & $\sqrt{ }$ & & $\sqrt{ }$ & & \\
\hline & Physics & & & & $\sqrt{ }$ & & $\sqrt{ }$ & & \\
\hline \multirow{3}{*}{$\begin{array}{l}\text { Delta } \\
\text { Central }\end{array}$} & Biology & & & & $\sqrt{ }$ & & $\sqrt{ }$ & & \\
\hline & Chemistry & & & & $\sqrt{ }$ & & $\sqrt{ }$ & & \\
\hline & Physics & & & & $\sqrt{ }$ & & $\sqrt{ }$ & & \\
\hline Delta & Biology & & & & $\sqrt{ }$ & & $\sqrt{ }$ & & \\
\hline \multirow{2}{*}{ South } & Chemistry & & & & $\sqrt{ }$ & & $\sqrt{ }$ & & \\
\hline & Physics & & & & $\sqrt{ }$ & & $\sqrt{ }$ & & \\
\hline State & Biology & & & & $\sqrt{ }$ & & $\sqrt{ }$ & & \\
\hline \multirow{2}{*}{ Average } & Chemistry & & & & $\sqrt{ }$ & & $\sqrt{ }$ & & \\
\hline & Physics & & & & $\sqrt{ }$ & & $\sqrt{ }$ & & \\
\hline
\end{tabular}


Table 6: Supervision of science instruction in classrooms.

\begin{tabular}{|c|c|c|c|c|c|c|c|c|c|}
\hline \multirow{2}{*}{$\begin{array}{l}\text { Senatorial } \\
\text { district }\end{array}$} & \multirow{2}{*}{$\begin{array}{l}\text { Science } \\
\text { subject }\end{array}$} & \multicolumn{4}{|c|}{ Public schools } & \multicolumn{4}{|c|}{ Private schools } \\
\hline & & $\begin{array}{c}\text { School } \\
\text { Principal }\end{array}$ & $\begin{array}{c}\text { Vice } \\
\text { Principal }\end{array}$ & $\begin{array}{c}\text { Subject } \\
\text { Head }\end{array}$ & $\begin{array}{c}\text { No. } \\
\text { specific } \\
\text { Person }\end{array}$ & $\begin{array}{c}\text { School } \\
\text { Principal }\end{array}$ & $\begin{array}{c}\text { Vice } \\
\text { Principal }\end{array}$ & $\begin{array}{c}\text { Subject } \\
\text { Head }\end{array}$ & $\begin{array}{c}\text { No. } \\
\text { specific } \\
\text { Person }\end{array}$ \\
\hline \multirow{3}{*}{$\begin{array}{l}\text { Delta } \\
\text { North }\end{array}$} & Biology & $\sqrt{ }$ & $\sqrt{ }$ & & & $\sqrt{ }$ & $\sqrt{ }$ & & \\
\hline & Chemistry & $\sqrt{ }$ & $\sqrt{ }$ & & & $\sqrt{ }$ & $\sqrt{ }$ & & \\
\hline & Physics & $\sqrt{ }$ & $\sqrt{ }$ & & & $\sqrt{ }$ & $\sqrt{ }$ & & \\
\hline \multirow{3}{*}{$\begin{array}{l}\text { Delta } \\
\text { Central }\end{array}$} & Biology & $\sqrt{ }$ & $\sqrt{ }$ & & & $\sqrt{ }$ & $\sqrt{ }$ & & \\
\hline & Chemistry & $\sqrt{ }$ & $\sqrt{ }$ & & & $\sqrt{ }$ & $\sqrt{ }$ & & \\
\hline & Physics & $\sqrt{ }$ & $\sqrt{ }$ & & & $\sqrt{ }$ & $\sqrt{ }$ & & \\
\hline Delta & Biology & $\sqrt{ }$ & $\sqrt{ }$ & & & $\sqrt{ }$ & $\sqrt{ }$ & & \\
\hline \multirow[t]{2}{*}{ South } & Chemistry & $\sqrt{ }$ & $\sqrt{ }$ & & & $\sqrt{ }$ & $\sqrt{ }$ & & \\
\hline & Physics & $\sqrt{ }$ & $\sqrt{ }$ & & & $\sqrt{ }$ & $\sqrt{ }$ & & \\
\hline State & Biology & $\sqrt{ }$ & $\sqrt{ }$ & & & $\sqrt{ }$ & $\sqrt{ }$ & & \\
\hline \multirow[t]{2}{*}{ Average } & Chemistry & $\sqrt{ }$ & $\sqrt{ }$ & & & $\sqrt{ }$ & $\sqrt{ }$ & & \\
\hline & Physics & $\sqrt{ }$ & $\sqrt{ }$ & & & $\sqrt{ }$ & $\sqrt{ }$ & & \\
\hline
\end{tabular}

Table 7: Frequency of science instruction supervision.

\begin{tabular}{|c|c|c|c|c|c|c|c|c|c|}
\hline \multirow{2}{*}{$\begin{array}{l}\text { Senatorial } \\
\text { district }\end{array}$} & \multirow{2}{*}{$\begin{array}{c}\text { Science } \\
\text { subject }\end{array}$} & \multicolumn{4}{|c|}{ Public schools } & \multicolumn{4}{|c|}{ Private schools } \\
\hline & & $\begin{array}{l}\text { Routine } \\
\text { Exercise }\end{array}$ & $\begin{array}{c}\text { When } \\
\text { noise } \\
\text { is heard }\end{array}$ & $\begin{array}{l}\text { Expecting } \\
\text { school } \\
\text { inspectors }\end{array}$ & $\begin{array}{c}\text { Rarely } \\
\text { done }\end{array}$ & $\begin{array}{l}\text { Routine } \\
\text { Exercise }\end{array}$ & $\begin{array}{c}\text { When } \\
\text { noise } \\
\text { is heard }\end{array}$ & $\begin{array}{c}\text { Expecting } \\
\text { school } \\
\text { inspectors }\end{array}$ & $\begin{array}{c}\text { Rarely } \\
\text { done }\end{array}$ \\
\hline \multirow{3}{*}{$\begin{array}{l}\text { Delta } \\
\text { North }\end{array}$} & Biology & & $\sqrt{ }$ & $\sqrt{ }$ & & \multicolumn{4}{|c|}{$\sqrt{ }$} \\
\hline & Chemistry & & $\sqrt{ }$ & $\sqrt{ }$ & & \multicolumn{4}{|c|}{$\sqrt{ }$} \\
\hline & Physics & & $\sqrt{ }$ & $\sqrt{ }$ & & \multicolumn{4}{|c|}{$\sqrt{ }$} \\
\hline \multirow{3}{*}{$\begin{array}{l}\text { Delta } \\
\text { Central }\end{array}$} & Biology & & $\sqrt{ }$ & $\sqrt{ }$ & & \multicolumn{4}{|c|}{$\sqrt{ }$} \\
\hline & Chemistry & & $\sqrt{ }$ & $\sqrt{ }$ & & \multicolumn{4}{|c|}{$\sqrt{ }$} \\
\hline & Physics & & $\sqrt{ }$ & $\sqrt{ }$ & & \multicolumn{4}{|c|}{$\sqrt{ }$} \\
\hline \multirow{3}{*}{$\begin{array}{l}\text { Delta } \\
\text { South }\end{array}$} & Biology & & $\sqrt{ }$ & $\sqrt{ }$ & & \multicolumn{4}{|c|}{$\sqrt{ }$} \\
\hline & Chemistry & & $\sqrt{ }$ & $\sqrt{ }$ & & \multicolumn{4}{|c|}{$\sqrt{ }$} \\
\hline & Physics & & $\sqrt{ }$ & $\sqrt{ }$ & & & $\sqrt{ }$ & & \\
\hline \multirow{3}{*}{$\begin{array}{l}\text { State } \\
\text { Average }\end{array}$} & Biology & & $\sqrt{ }$ & $\sqrt{ }$ & & \multirow{2}{*}{\multicolumn{4}{|c|}{$\sqrt{ }$}} \\
\hline & Chemistry & & & & & & & & \\
\hline & physics & & $\sqrt{ }$ & $\sqrt{ }$ & & \multicolumn{4}{|c|}{$\sqrt{ }$} \\
\hline
\end{tabular}

Table 8: Organization of practical science lesson

\begin{tabular}{|c|c|c|c|c|c|c|c|c|c|c|c|}
\hline \multirow{2}{*}{$\begin{array}{l}\text { Senatorial } \\
\text { district }\end{array}$} & \multirow{2}{*}{$\begin{array}{l}\text { Science } \\
\text { subjects }\end{array}$} & \multicolumn{5}{|c|}{ Public schools } & \multicolumn{5}{|c|}{ Private schools } \\
\hline & & $\begin{array}{l}\text { Week- } \\
\text { ly }\end{array}$ & $\begin{array}{l}\text { Month- } \\
\text { ly }\end{array}$ & $\begin{array}{c}\text { Term } \\
\text { ly }\end{array}$ & $\begin{array}{l}\text { Expect } \\
\text { ing } \\
\text { external } \\
\text { exami- } \\
\text { nation }\end{array}$ & $\begin{array}{c}\text { Not } \\
\text { at } \\
\text { all }\end{array}$ & $\begin{array}{l}\text { Week- } \\
\text { ly }\end{array}$ & $\begin{array}{c}\text { Month- } \\
\text { ly }\end{array}$ & $\begin{array}{c}\text { Term } \\
\text { ly }\end{array}$ & $\begin{array}{l}\text { Expect } \\
\text { ing } \\
\text { external } \\
\text { exami- } \\
\text { nation }\end{array}$ & $\begin{array}{c}\text { Not } \\
\text { at } \\
\text { all }\end{array}$ \\
\hline Delta & Biology & & & & $\sqrt{ }$ & & & $\sqrt{ }$ & & $\sqrt{ }$ & \\
\hline North & $\begin{array}{l}\text { Chemistry } \\
\text { Physics }\end{array}$ & & & & $\begin{array}{l}\sqrt{ } \\
\sqrt{ }\end{array}$ & & & & $\sqrt{ }$ & $\begin{array}{l}\sqrt{ } \\
\sqrt{ }\end{array}$ & \\
\hline Delta & Biology & & & & $\sqrt{ }$ & & & $\sqrt{ }$ & & $\sqrt{ }$ & \\
\hline Central & $\begin{array}{l}\text { Chemistry } \\
\text { Physics }\end{array}$ & & & & $\begin{array}{l}\sqrt{ } \\
\sqrt{ }\end{array}$ & & & & $\sqrt{ }$ & $\begin{array}{l}\sqrt{ } \\
\sqrt{ }\end{array}$ & \\
\hline Delta & Biology & & & & $\sqrt{ }$ & & & $\sqrt{ }$ & & $\sqrt{ }$ & \\
\hline South & $\begin{array}{l}\text { Chemistry } \\
\text { Physics }\end{array}$ & & & & $\begin{array}{l}\sqrt{ } \\
\sqrt{ }\end{array}$ & & & & $\sqrt{ }$ & $\begin{array}{l}\sqrt{ } \\
\sqrt{ }\end{array}$ & \\
\hline State & Biology & & & & $\sqrt{ }$ & & & $\sqrt{ }$ & & $\sqrt{ }$ & \\
\hline Average & $\begin{array}{l}\text { Chemistry } \\
\text { Physics }\end{array}$ & & & & $\begin{array}{l}\sqrt{ } \\
\sqrt{ }\end{array}$ & & & & $\sqrt{ }$ & $\begin{array}{l}\sqrt{ } \\
\sqrt{ }\end{array}$ & \\
\hline
\end{tabular}


Table 9: Organisation of extra lessons to cover syllabus.

\begin{tabular}{|c|c|c|c|c|c|c|c|c|c|}
\hline \multirow{2}{*}{$\begin{array}{l}\text { Senatorial } \\
\text { district }\end{array}$} & \multirow{2}{*}{$\begin{array}{l}\text { Science } \\
\text { subject }\end{array}$} & \multicolumn{4}{|c|}{ Public schools } & \multicolumn{4}{|c|}{ Private schools } \\
\hline & & $\begin{array}{c}\text { Often } \\
\text { students } \\
\text { pay }\end{array}$ & $\begin{array}{c}\text { Often } \\
\text { students } \\
\text { do not } \\
\text { pay }\end{array}$ & $\begin{array}{c}\text { For } \\
\text { only } \\
\text { certificate } \\
\text { classes on } \\
\text { payment }\end{array}$ & $\begin{array}{c}\text { No } \\
\text { extra } \\
\text { lessons }\end{array}$ & $\begin{array}{c}\text { Often } \\
\text { students } \\
\text { pay }\end{array}$ & $\begin{array}{c}\text { Often } \\
\text { students } \\
\text { do not } \\
\text { pay }\end{array}$ & $\begin{array}{c}\text { For } \\
\text { only } \\
\text { certificate } \\
\text { classes on } \\
\text { payment }\end{array}$ & $\begin{array}{c}\text { No } \\
\text { extra } \\
\text { lessons }\end{array}$ \\
\hline Delta & Biology & & & $\sqrt{ }$ & & $\sqrt{ }$ & & & \\
\hline North & $\begin{array}{l}\text { Chemistry } \\
\text { Physics }\end{array}$ & & & $\begin{array}{l}\sqrt{ } \\
\sqrt{ }\end{array}$ & & $\begin{array}{l}\sqrt{ } \\
\sqrt{ }\end{array}$ & & & \\
\hline Delta & Biology & & & $\sqrt{ }$ & & $\sqrt{ }$ & & & \\
\hline Central & $\begin{array}{l}\text { Chemistry } \\
\text { Physics }\end{array}$ & & & $\begin{array}{l}\sqrt{ } \\
\sqrt{ }\end{array}$ & & $\begin{array}{l}\sqrt{ } \\
\sqrt{ }\end{array}$ & & & \\
\hline Delta & Biology & & & $\sqrt{ }$ & & $\sqrt{ }$ & & & \\
\hline South & $\begin{array}{l}\text { Chemistry } \\
\text { Physics }\end{array}$ & & & $\begin{array}{l}\sqrt{ } \\
\sqrt{ }\end{array}$ & & $\begin{array}{l}\sqrt{ } \\
\sqrt{ }\end{array}$ & & & \\
\hline $\begin{array}{l}\text { State } \\
\text { Average }\end{array}$ & $\begin{array}{l}\text { Biology } \\
\text { Chemistry } \\
\text { Physics }\end{array}$ & & & $\begin{array}{l}\sqrt{ } \\
\sqrt{ } \\
\sqrt{ }\end{array}$ & & $\begin{array}{l}\sqrt{ } \\
\sqrt{ } \\
\sqrt{ }\end{array}$ & & & \\
\hline
\end{tabular}

on the condition that they pay a fee charged by the school authority. For the private schools the organization of extra lessons is routine, which cut across all classes and the students pay fees for the lessons.

\section{Assessment of Learning Outcome}

Shown in Table 10, the assessment of learning outcome in science subjects in public schools is by using a combination of ministry of education set and school set examinations. The private schools mainly use their school set examinations in assessing their science students. Table 11 shows that in both public and private schools in the state, the main learning outcomes assessed in all the forms of examinations is cognitive.

\section{DISCUSSION}

The findings of this study are significant in two ways. First, findings of the study have been able to expose the activities, which go on in most science classrooms. The findings will therefore serve as a springboard for innovations in science teaching, which will enhance science learning. The findings will also serve as bases for offering useful suggestions to all stakeholders in science education. The second significance of the study is that findings will offer us the opportunity to compare our methods and procedure of teaching and learning science with international standards. The findings will open the door for improvement in science teaching, which will take science learning to a higher level.

Table 10: Assessment of learning-outcome in sciences.

\begin{tabular}{|c|c|c|c|c|c|c|c|c|c|c|c|}
\hline \multirow{2}{*}{$\begin{array}{l}\text { Senatorial } \\
\text { district }\end{array}$} & \multirow{2}{*}{$\begin{array}{l}\text { Science } \\
\text { subjects }\end{array}$} & \multicolumn{5}{|c|}{ Public schools } & \multicolumn{5}{|c|}{ Private schools } \\
\hline & & $\begin{array}{l}\text { State } \\
\text { set } \\
\text { exams }\end{array}$ & $\begin{array}{c}\text { School } \\
\text { set } \\
\text { exams }\end{array}$ & $\begin{array}{l}\text { Subject } \\
\text { teachers } \\
\text { private } \\
\text { exams }\end{array}$ & $\begin{array}{l}\text { Expect } \\
\text { ing } \\
\text { external } \\
\text { exams }\end{array}$ & $\begin{array}{l}\text { Not } \\
\text { exams } \\
\text { at } \\
\text { all }\end{array}$ & $\begin{array}{l}\text { State } \\
\text { set } \\
\text { exams }\end{array}$ & $\begin{array}{c}\text { School } \\
\text { set } \\
\text { exams }\end{array}$ & $\begin{array}{l}\text { Subject } \\
\text { teachers } \\
\text { private } \\
\text { exams }\end{array}$ & $\begin{array}{c}\text { Expect } \\
\text { ing } \\
\text { external } \\
\text { exams }\end{array}$ & $\begin{array}{c}\text { Not } \\
\text { exams } \\
\text { at } \\
\text { all }\end{array}$ \\
\hline \multirow{3}{*}{$\begin{array}{l}\text { Delta } \\
\text { North }\end{array}$} & Biology & $\sqrt{ }$ & $\sqrt{ }$ & & & & & $\sqrt{ }$ & & & \\
\hline & Chemistry & $\sqrt{ }$ & $\sqrt{ }$ & & & & & $\sqrt{ }$ & & & \\
\hline & Physics & $\sqrt{ }$ & $\sqrt{ }$ & & & & & $\sqrt{ }$ & & & \\
\hline \multirow{3}{*}{$\begin{array}{l}\text { Delta } \\
\text { Central }\end{array}$} & Biology & $\sqrt{ }$ & $\sqrt{ }$ & & & & & $\sqrt{ }$ & & & \\
\hline & Chemistry & $\sqrt{ }$ & $\sqrt{ }$ & & & & & $\sqrt{ }$ & & & \\
\hline & Physics & $\sqrt{ }$ & $\sqrt{ }$ & & & & & $\sqrt{ }$ & & & \\
\hline \multirow{3}{*}{$\begin{array}{l}\text { Delta } \\
\text { South }\end{array}$} & Biology & $\sqrt{ }$ & $\sqrt{ }$ & & & & & $\sqrt{ }$ & & & \\
\hline & Chemistry & $\sqrt{ }$ & $\sqrt{ }$ & & & & & $\sqrt{ }$ & & & \\
\hline & Physics & $\sqrt{ }$ & $\sqrt{ }$ & & & & & $\sqrt{ }$ & & & \\
\hline \multirow{3}{*}{$\begin{array}{l}\text { State } \\
\text { Average }\end{array}$} & Biology & $\sqrt{ }$ & $\sqrt{ }$ & & & & & $\sqrt{ }$ & & & \\
\hline & Chemistry & $\sqrt{ }$ & $\sqrt{ }$ & & & & & $\sqrt{ }$ & & & \\
\hline & Physics & $\sqrt{ }$ & $\sqrt{ }$ & & & & & $\sqrt{ }$ & & & \\
\hline
\end{tabular}


Table 11: Type of learning-outcome assessed by science teachers.

\begin{tabular}{|c|c|c|c|c|c|c|}
\hline \multirow{2}{*}{$\begin{array}{l}\text { Senatorial } \\
\text { district }\end{array}$} & \multirow{2}{*}{$\begin{array}{l}\text { Science } \\
\text { subject }\end{array}$} & \multicolumn{2}{|r|}{ Public schools } & \multicolumn{3}{|c|}{ Private schools } \\
\hline & & Cognitive & Psychomotor Affective & Cognitive & Psychomotor & Affective \\
\hline Delta & Biology & $\sqrt{ }$ & & $\sqrt{ }$ & & \\
\hline \multirow[t]{2}{*}{ North } & Chemistry & $\begin{array}{l}\sqrt{ } \\
\sqrt{ }\end{array}$ & & $\begin{array}{l}\sqrt{ } \\
\sqrt{ }\end{array}$ & & \\
\hline & Physics & $\sqrt{ }$ & & $\sqrt{ }$ & & \\
\hline Delta & Biology & $\sqrt{ }$ & & $\sqrt{ }$ & & \\
\hline \multirow[t]{2}{*}{ Central } & Chemistry & $\sqrt{ }$ & & $\sqrt{ }$ & & \\
\hline & Physics & $\sqrt{ }$ & & $\sqrt{ }$ & & \\
\hline Delta & Biology & $\sqrt{ }$ & & $\sqrt{ }$ & & \\
\hline \multirow[t]{2}{*}{ South } & Chemistry & $\sqrt{ }$ & & $\sqrt{ }$ & & \\
\hline & Physics & $\sqrt{ }$ & & $\sqrt{ }$ & & \\
\hline State & Biology & $\sqrt{ }$ & & $\sqrt{ }$ & & \\
\hline \multirow[t]{2}{*}{ Average } & Chemistry & $\sqrt{ }$ & & $\sqrt{ }$ & & \\
\hline & Physics & $\sqrt{ }$ & & $\sqrt{ }$ & & \\
\hline
\end{tabular}

The finding of two single periods and one double period allocated to all science subjects in the school time table indicates that the science subjects are taught only three times a week. The double period was to be used for practical demonstration of concepts, which are not done in most of the schools in the state. This situation is so because of lack of proper implementation of the national policy on education. The provision in the national policy on education was that the result of Junior Secondary School Certificate examination be the bases for distribution of students into Science, Arts and Social Science classes. This limits the subjects the students in the various classes offer, thus paving way for more periods to be allocated to core subjects' in different disciplines. This is however not the practice in most schools. Most schools stills have classes that are mixture of Science, Arts and Social Science Students. This has resulted in inadequate periods being allocated to some core subjects like the sciences in the school timetable.

The pattern of interaction in most of the science classrooms is the teacher initiated and dominated teacher-student interaction. This does not agree with international standards which recommend that teachers should interact with students to focus and support their inquiries Trowbridge and Bybee (1996). The finding also fell below the recommendation of co-operative learning for teaching for effective learning Johnson and Johnson (1991) which encourages student-student interaction. Borich (2004) noted that because of student-student interaction, in co-operative learning groups, students gradually take responsibility for each other's learning. The student-teacher interaction was dominant among the sampled schools because of the method of instruction which is expository (classroom teaching method). The major limitation of expository method of teaching is that the students are always passive. The finding of expository method as the major method of teaching sciences in schools agrees with the findings of (Ajaja 1998, 2002, 2005) who made similar findings in different local government areas of Delta State.

On coverage of content materials in the science schemes of work, it was found that a reasonable percentage of content materials are not covered in the public schools. The non-coverage of a reasonable amount of science content materials in public schools can be explained to be the direct effects of frequent and protracted strike the teachers in the public schools embark on to press home their demands. Even now all teachers in public school throughout the country have been on strike for over a month. This has paralysed the conduct of Senior Certificate examinations. This may be one of the reasons why students fail in science examinations.

On the noticed inconsistency in the giving and marking of assignments as found among public schools, the principals and the inspectorate division of the state ministry of education is to be blamed. If you give someone a responsibility, it is important to find out if the responsibility is carried out the way you want it. The teachers are employed without putting in place competent hands to supervise their activities. This again does not agree with international standard of science teaching which recommends that teachers should engage in ongoing assessment of their teaching and resulting students learning Trowbridge and Bybee (1996).

The supervision of all school instructions by the principal and his vice and only when there is 
noise emanating from a class and when expecting ministry of education inspectors is not healthy for proper teaching and learning. The normal supervision of instruction that will guarantee effective teaching and learning is the one done by the subject specialist and routinely done. Instructional inspection should be done in such a way that at the end of the day the teacher benefits from the inspector in teaching improvement.

The organization of extra-lessons by dedicated teachers is mainly to enable them cover lost grounds for one reason or the other. It helps in better positioning of students preparing for centrally set examinations. The students were not supposed to have paid for such lessons since it was the responsibility of the teachers to have covered the schemes of work meant for the various classes. The tying of extra lesson to payment of fees is a deviation from the norm. This may explain the poor attitude of some students towards sciences. Such students have suffered from lack of motivation and encouragement from their science teachers.

The practical lessons are what make science real and remove it from abstraction. Practical lessons help to demonstrate concepts learned in theory. The non-organisation of practical lessons except when preparing for senior school certificate examination in public schools is again a deviation from the national and international standards. This has affected the acquisition of the necessary skills for performing experiments in science. WAEC examiners Report on sciences (2004) stated that most of the candidates fail practical examinations because they lack the basic skill for doing simple experiments in sciences. The nonconduct of practicals in public schools may not be unconnected with government's inability to provide well-equipped science laboratories.

The assessment of students in public schools with both ministry and school set examinations, agrees with the decision of the state ministry of education. The public schools examine their individual students for first and second terms. In the third term all the public schools write one examination that is centrally set. The private schools do not participate in such examination. The ministry of education maintained that the aim is to maintain standard among the public schools. This again does not agree with international standards where all high schools are autonomous in conducting internal examinations.

The centralization of school science assess- ment mainly on cognitive domain is a clear deviation from both national and international standards. The national standard as recommended in the national policy on education is that learners should be assessed roundly and that assessment should be continuous. The all-round assessment means assessment of Cognitive, Affective and Psychomotor domains.

\section{CONCLUSION}

The findings of this study indicate that so many things are wrong with the teaching of the sciences in Delta State. Apart from the poor state of infrastructure which has negatively influenced the teaching of science in the state, the science teachers themselves are not well positioned to teach science effectively. Their deficiencies range from the use of inappropriate teaching methods for teaching sciences, through lack of commitment and dedication to inaccurate assessment of students learning outcome in science.

The problem of poor teaching of sciences in our schools can therefore be hinged on the dearth of resources for teaching science, large class sizes of science students, very few qualified science teachers and competency problems' arising from the poor training of science teachers. The existence of these problems is known to influence effective teaching and learning of science.

The situation therefore calls for the retraining of all science teachers in the state, through seminars and workshops and provision of infrastructure to reposition science teaching in the state. This will enable teachers teach science in line with national standards and aspire to catchup with international specifications.

\section{RECOMMENDATIONS}

Based on the findings of this study, the following recommendations were made:

School owners should employ more science teachers particularly in physics and chemistry. The lower the work load of science teacher, the more effective they will be.

All science teachers as presently constituted; should be retrained to give them a better orientation on what is expected of them. The retraining will expose them to current methods of teaching and presenting content materials to learners.

All school heads and every other persons 
involved with supervision of instruction should be alive with their responsibilities. Supervision of instruction will reduce laxity among science teachers and their students.

Science teachers and government should religiously follow the specifications in the National Policy on Education in the implementations of the Science curriculum in use. The government should provide the necessary infrastructure and enabling environment to make science education thrive.

\section{ABBREVIATIONS}

(A) WAEC: West African Examination Council

(B) CESAC: Comparative Education Study and Adaptive Centre.

\section{NOTES}

(i) Period: This is the amount of time a lesson lasts.

(ii) Pattern of interaction: This is the disposition of teachers and students during instruction. There are teacher-student, and student-student interactions.

(iii) Public schools: These are schools owned by the governments which are either, federal, state or local government.

(iv) Private schools: These are schools owned by private individuals, or organizations.

\section{REFERENCES}

Abijo Ayo 1981. An evaluation of the Comparative Education Study and Adaptive Centre (CESAC) Chemistry Programme M.Ed Dissertation, Unpublished, Ibadan: University of Ibadan.

Aghenta JA 1982. Why there are not enough science applicants for university admission in Nigeria. Journal of STAN, 20(2): 90 - 99.

Ajaja Patrick 1998. An Evaluation of a Differential Effectiveness of Ausbel, Burner, and Karplus Methods of Teaching Biology in Nigeria Secondary Schools. Ph.D Thesis, Unpublished, Benin: University of Benin.

Ajaja OP 2002. Assessment of biology study support environment in our schools. STAN Annual Conference and Inaugural Conference of CASTME Africa, 43: 215-218.

Ajaja OP 2005. Comparison of the effectiveness of three instructional methods (Advance Organizer, Discover and Invention) on exhibition of acceptable laboratory' behaviours. Journal of Vocational Science and Educational Development, 6(1 \& 2): 36 - 44
Ajaja OP 2007. Teaching Methods Across Disciplines. Agbor: Allwell Publications.

Aminu DM 1980. Integrated science teachers in Kaduna State: Students Perception. Journal of Science Teachers' Association of Nigeria, 18(2): 83-88.

Borich GD 2004. Effective Teaching Methods. Fifth edition. New Jersey: Pearson Merrill Prentice Hall.

Evans CS 1986. Philosophy of Science: The Natural Sciences in Christian Perspective. Illinois: Intervarsity Press.

Federal Republic of Nigeria 2004. National Policy on Education. Lagos: Federal Ministry of Education.

Ivonwi U 1997. Competences required of teachers in the 6-3-3-4 system of education for the secondary schools. In: Ben Akpan (Ed): Perspectives on Education and Science Teaching from the Eyes of Uduogie Ivowi. Abuja: Foremost Educational Service Ltd., pp.125-132.

Jegede OJ 1982. Evaluation of present Nigeria integrated science project. The New Nigerian Integrated Science Project and the 3-3 Secondary School System, 1: 2-16.

Johnson B, Christensen L 2000. Educational Research. Boston: Allyn and Bacon.

Johnson D, Johnson R 1991. Learning Together and Alone. $3^{\text {rd }}$ Edition. Upper Saddle River, N.J: Prentice Hall.

Kpangban E, Ajaja OP 2004. Effect of observation on biology students exhibition of laboratory behaviours and achievement. Standardizer of the Nigerian Academics, I(1): 3 -39.

Onwuka U 1985. Curriculum development for Africa Onsitha: Africana- FEP Publishers Ltd.

Oludofun J S Oguniyi O 1981 The Performance of selected Physics teachers relative to the objectives of CESAC Programme. Nigerian Journal of Curriculum Studies, II(2): 142-150.

Trowbridge LW, Bybee RW 1996. Teaching Secondary School Science, Strategies for Developing Scientific Literacy. New Jersey: Merrill, Prentice Hall.

Ughamadu KA 2005. Curriculum: Concept, Development and Implementation. Onisha: Emba Printing and Publishing Company Ltd.

Urevbu A O1997. Creating the School We Deserve. Benin City: University of Benin Press.

Wiseman DC 1999. Research Strategies for Education. New York: Wadsworth Publishing Company.

WAEC 2004. Chief Examiner Report. Lagos: WAEC Press Ltd.

WAEC 2005. Chief Examiner Report. Lagos: WAEC Press Ltd.

WAEC 2006. Chief Examiner Report. Lagos: WAEC Press Ltd

WAEC 2007. Chief Examiner Report. Lagos: WAEC Press Ltd. 